\title{
KELAS UKURAN DAN NISBAH KELAMIN IKAN SEMBILANG (Plotosus canius) DI SUNGAI BELAWAN
}

\section{THE SIZE CLASS AND SEX RATIO BLACK EELTAIL CATFISH (Plotosus canius) IN THE BELAWAN RIVER}

\author{
USWATUL HASAN ${ }^{1 *}$ ), DWI TIKA AFRIANI ${ }^{2}$ ) \\ ${ }^{1,2}$ ) Program Studi Akuakultur Fakultas Perikanan Universitas Dharmawangsa Medan \\ Jl. Komondor Laut Yos Sudarso No.224 Medan \\ e-mail: uswatulhasan516@yahoo.com
}

Diterima Mei 2019 dan Disetujui Juni 2019

\begin{abstract}
Abstrak. Ikan sembilang adalah salah satu ikan yang mempunyai nilai ekonomis penting bagi masyarakat. Ikan ini biasa ditangkap nelayan di perairan Sungai Belawan. Kelas ukuran dan nisbah kelamin menjadi patokan penentuan harga di pasaran. Tujuan peneitian ini adalah untuk mengetahui kelas ukuran dan nisbah kelamin ikan sembilang di Sungai Belawan. Pengambilan sampling ikan dimulai pada bulan Maret -Mei 2019. Penangkapan ikan menggunakan bubu dan pancing. Penentuan stasiun pengamatan pada penelitian ini menggunakan teknik purposive random sampling menggunakan Global Positioning System (GPS). Ikan diambil pada 3 titik stasiun pengamatan yang ditentukan berdasarkan luas badan perairan. Ikan yang tertangkap dilakukan pengukuran panjang totalnya.. Analisis data menggunakan Aplikasi Microsoft Excel 2010. Berdasarkan hasil penelitian kelas ukuran ikan sembilang tertangkap didominasi ukuran sedang (13 ekor), ukuran besar (7ekor), dan ukuran kecil (6 ekor). Selanjutnya nisbah kelamin ikan jantan sebesar 38,46\% dan ikan betina sebesar $51,54 \%$.
\end{abstract}

Kata Kunci: ikan sembilang, kelas ukuran, nisbah kelamin, sungai belawan

\begin{abstract}
Black Eeltail Catfish is one of the fish that has an important economical value for the community. This fish is commonly arrested by fishermen in the Belawan River. The class size and the sex ratio become the benchmark price in the market. The purpose of this insulation is to know the class of size and the sex ratio of fish in the Belawan River. Sampling of fish was initiated in March-May 2019. Fishing using bottom trap and fishing rods. The determination of the observation station on this study used purposive random sampling technique using Global Positioning System (GPS). Fish taken at 3 point observation stations determined by the area of water body. The fish caught in the total length measurements. Analyze data using Microsoft Excel applications 2010. Based on the results of the study of the size of fish is semantically caught in medium size (13 species), large size ( 7 species), and small size ( 6 species). The sex ratio of the male was $38.46 \%$ and the female fish was $51.54 \%$.
\end{abstract}

Keywords: black eeltail catfish, size class, sex ratio, belawan river

\section{PENDAHULUAN}

Ikan memegang peranan penting dalam pemenuhan sumber gizi dan keamanan hidup bagi manusia pada negara berkembang [1]. Selanjutnya Ikan juga berfungsi sebagai sumber dari asam lemak tidak jenuh jamak (PUFA), protein, mineral dan vitamin. Selain merupakan komoditas yang mudah dijumpai, ikan memiliki kelebihan nutrisi dibanding dengan produk hewani lain yaitu ikan mengandung asam lemak tak jenuh dan kolesterol yang sangat rendah sehingga aman dikonsumsi secara rutin

Ikan Sembilang (Plotosus canius) merupakan salah satu sumberdaya perikanan ekonomis penting yang tergolong dalam family Plotosidae [2]. Diketahui, hanya ada dua jenis sembilang yang hidup di Indonesia dari suku Plotosidae, yaitu sembilang karang yang belang hitam putih dan sembilang yang umum dikenal seperti ikan lele [3]. Di kawasan pesisir Belawan ikan sembilang merupakan salah satu ikan yang sangat digemari oleh masyarakat. Harga ikan sembilang bisa mencapai Rp. 25.000,- sampai dengan Rp. 40.000,- per kilogram. Ukuran ikan yang lebih besar dan yang betina bertelur harganya bisa lebih mahal.

Upaya penangkapan ikan sembilang yang dilakukan secara terus-menerus, dikhawatirkan akan menganggu proses rekruitmen karena banyak ikan yang kecil tertangkap. Pemanfaatan sumber daya ikan secara berkelanjutan pada dasarnya adalah tujuan dari pengelolaan yang menjamin tingkat 
$\mathcal{H a l}: 26-30$

pemanfaatan sumber daya yang tidak merusak atau melampaui daya pulinnya, sehingga dapat memenuhi kebutuhan hidup generasi masa kini maupun generasi yang akan datang [4].

Sampai saat ini data dan informasi mengenai ukuran kelas dan nisbah kelamin ikan sembilang masih sangat kurang. Padahal upaya optimalisasi penangkapan, pemanfaatan, serta pelestarian ikan sembilang di suatu perairan memerlukan suatu informasi mengenai aspek bioekologi ikan sembilang. Kelas ukuran dan nisbah kelamin merupakan suatu hal yang penting bagi keberlangsungan kehidupan serta kelestarian sumber daya ikan sembilang di suatu perairan. Oleh karena itu, studi mengenai kelas ukuran dan nisbah kelamin ikan sembilang sangat diperlukan. Hal ini diperlukan untuk mengetahui kondisi status populasi ikan sembilang di perairan Sungai Belawan.

\section{METODE PENELITIAN \\ Waktu dan Tempat}

Penelitian ini dilaksanakan mulai bulan Maret sampai Mei 2019, bertempat di Sungai Belawan Kelurahan Belawan Sicanang Kecamatan Medan Belawan, Kota Medan Propinsi Sumatera Utara.

\section{Jenis Penelitian}

Penelitian ini merupakan penelitian eksploratif, dimana penelitian ini mengkaji aspek bioekologi ikan sembilang terkait kelas ukuran dan nisbah kelamin berdasarkan data yang didapatkan dari hasil pengamatan langsung di lapangan.

\section{Metode Penelitian}

Penelitian ini menggunakan metode purposive random sampling. yakni teknik menentukan titik pengambilan sampling dengan beberapa pertimbangan tertentu, dalam hal ini penentuan stasiun pengamatan berdasarkan perbedaan lebar badan sungai yang tujuannya agar data yang diperoleh lebih mewakili.

\section{Prosedur Penelitian}

\section{Penentuan Stasiun Pengamatan.}

Stasiun pengamatan ditentukan berdasarkan perbedaan lebar badan perairan yakni:

1. Stasiun 1 lebar sungai $\pm 50 \mathrm{~m}$

2. Stasiun 2 lebar sungai $\pm 200 \mathrm{~m}$

3. Stasiun 3 lebar sungai $\pm 100 \mathrm{~m}$

Penentuan titik koordinat pada stasiun pengamatan mengunakan Global Positioning System (GPS). Peta lokasi penelitian dapat dilihat pada gambar 1 di bawah ini

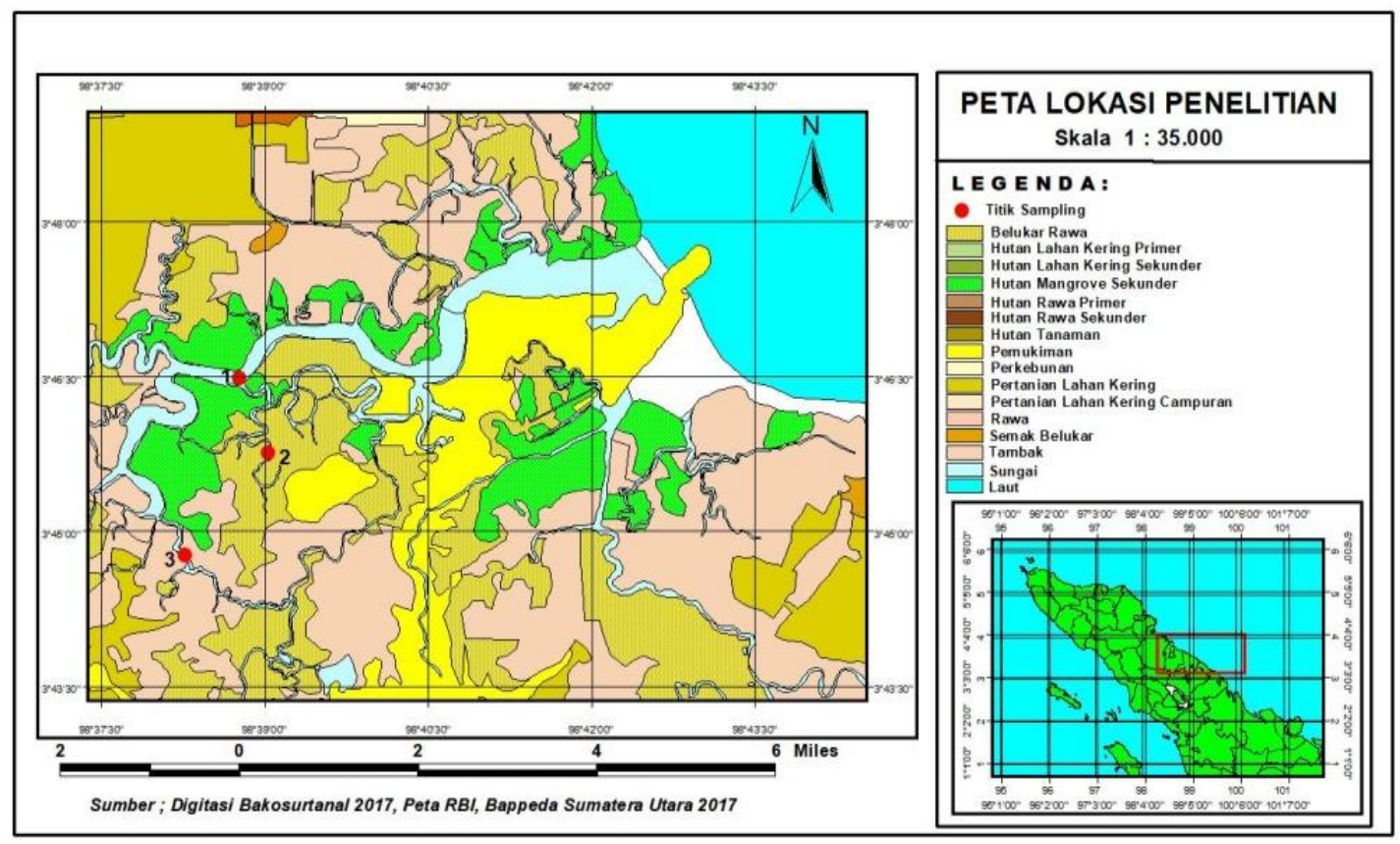

Gambar 1. Peta Lokasi Penelitian 
$\mathcal{H a l}: 26-30$

\section{Teknik Penangkapan}

Pengambilan sampel ikan menggunakan alat tangkap bubu dan pancing. Ikan hasil tangkapan kemudian dilakukan pengukuran panjang total dan diperikasa jenis kelaminnya berdasarkan karakteristik sex primernya. Pemasangan bubu dan pancing pada stasiun pengamatan sebanyak 3 buah, hal ini dianggap sebagai ulangan. Pengambilan sampling dilakukan sebanyak 3 kali dan dilakukan masing-masing sekali pada setiap bulannya, yakni pada bulan Maret, April, dan Mei 2019. Ikan sembilang yang tertangkap diawetkan dengan alkohol $70 \%$ untuk selanjutnya dilakukan identifikasi di Laboratorium Perikanan Universitas Dharmawangsa Medan mengunakan buku identifikasi Kottelat et al.,(1993) untuk mengetahui jenis spesiesnya.

\section{Analisis Data}

Data hasil penelitian dimasukan dalam tabulasi data untuk dilakukan analisis menggunakan Aplikasi Microsoft Excel 2010.

\section{HASIL DAN PEMBAHASAN \\ Kelas Ukuran}

Panjang Total (Total Lenght) yang digunakan untuk menentukan kelas ukuran pada ikan sembilang. Kelas ukuran ikan digolongkan ke dalam 3 kategori yakni: kecil, sedang, dan besar. Hasil tangkapan ikan sembilang di perairan Sungai Belawan berjumlah 26 ekor dengan rinciansebagai berikut: ikan kategori besar (7 ekor), ukuran sedang (13 ekor), dan ukuran kecil (6 ekor)). Selanjutnya data kelas ukuran ikan sembilang dilihat pada Tabel 1. di bawah ini

Tabel 1. Hasil Tangkapan ikan Sembilang Berdasarkan Kelas Ukuran

\begin{tabular}{lccc}
\hline Kelas Ukuran (cm) & \multicolumn{3}{c}{ Jumlah Hasil Tangkapan (ekor) } \\
\cline { 2 - 4 } & Stasiun 1 & Stasiun 2 & Stasiun 3 \\
\hline $20-24,9$ (Kecil) & 2 & 3 & 1 \\
$25-29,9$ (Sedang) & 5 & 4 & 4 \\
$>30$ (Besar) & 2 & 3 & 2 \\
\hline
\end{tabular}

Berdasarkan atas kelas ukuran, dalam hal ini dilihat dari ukuran panjang total ikan sembilang yang tertangkap, maka dapat diketahui ikan yang paling banyak tertangkap adalah pada ukuran sedang (13 ekor), diikuti ukuran besar ( 7 ekor), dan terakhir ukuran kecil (6 ekor). Hal ini diduga karena alat tangkap yang digunakan merupakan alat tangkap yang bersifat selektif, yakni pada pancing hanya pada ukuran tertentu saja ikan sembilang yang dapat tertangkap karena mata pancing yang digunakan dengan ukuran 15. Pada bubu juga merupakan alat tangkap yang selektif, ukuran ikan sembilang yang lebih kecil akan lolos, karena bubu tersebut dijalin agak jarang.

Selektivitas alat tangkap adalah penting dalam hal menyeleksi ukuran panjang ikan pertama kali tertangkap (length at first capture) dan jenis ikan yang tidak menjadi target utama dalam penangkapan. Untuk tujuan pelestarian sumber daya ikan upaya penangkapan yang disarankan adalah menangkap ikan-ikan yang sudah pernah memijah [5]. Selain itu Menurut [6] semakin besar ukuran panjang dan bobot tubuhnya semakin sedikit yang tertangkap, hal ini dikarenakan ikan sembilang sebelum mencapai ukuran dan bobot tersebut tertangkap oleh nelayan, sehingga tidak sempat tumbuh mencapai ukuran dan bobot tubuh yang maksimal. [4] menjelaskan alat tangkap pancing dan bubu dirasakan sangat sesuai dengan kondisi perairan di Tanjungpandan dan sekitarnya, demikian juga dengan alat tangkap yang digunakannya dirasakan aman bagi nelayan dan cukup ramah lingkungan, sehingga kedua atribut utama dari dimensi teknologi ini memberikan kontribusi baik bagi status keberlanjutan dan perlu dipertahankan.

\section{Nisbah Kelamin}

Ikan sembilang yang tertangkap selama 3 bulan pelaksanaan penelitian berjumlah 26 ekor, terdiri dari kelamin jantan 10 ekor $(38,46 \%)$ dan betina 16 ekor $(61,53 \%)$ atau dengan perbandingan $1: 1,5$. Selengkapnya data hasil tangkapan ikan sembilang berdasarkan jenis kelamin dapat dilihat pada gambar berikut ini: 
$\mathcal{H a l}: 26-30$

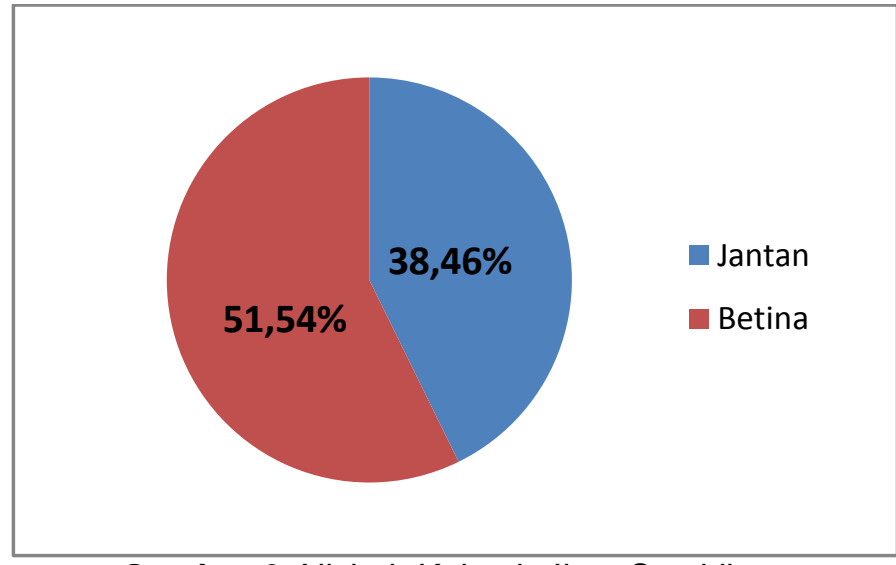

\section{Gambar 2. Nisbah Kelamin Ikan Sembilang}

Rasio kelamin diperlukan untuk mengetahui perbandingan jenis kelamin jantan dengan betina pada ikan sembilang, hal ini dimaksud agar dapat menduga keseimbangan populasinya. Populasi ikan sembilang betina di daerah penelitian lebih banyak dibandingkan dengan jantan. Hal ini dapat terjadi karena adanya kelebihan tangkap atau kegiatan penangkapan yang tidak terkendali. Perubahan nisbah kelamin dapat disebabkan oleh intensitas penangkapan yang tinggi, faktor lingkungan serta selektivitas alat tangkap. Hasil penelitian menunjukan tidak seimbangnya jumlah antara ikan jantan dan ikan betina dalam suatu populasi akan berdampak terhadap penurunan populasi ikan di alam. [7] menjelaskan perbedaan nisbah kelamin ini dapat disebabkan oleh tingkah laku bergerombol antara ikan jantan dan betina, kondisi lingkungan, dan faktor penangkapan. Selanjutnya [2] menyatakan bahwa untuk mempertahankan kelangsungan hidup suatu populasi, perbandingan jantan dan betina diharapkan berada dalam kondisi seimbang, setidaknya ikan betina lebih banyak.

\section{Kesimpulan}

Kelas ukuran ikan sembilang yang tertangkap yang terbanyak didominsi oleh ukuran sedang (13 ekor), diikuti ukuran besar (7 ekor), dan kecil (6 ekor). Hal ini diduga karena alat tangkap (pancing dan bubu) yang digunakan bersifat selektif. Nisbah kelamin ikan sembilang mempunyai rasio perbandingan $1 ; 1,5$. Hal ini diduga karena faktor penangkapan yang berlebih.

\section{Ucapan Terima Kasih}

Penulis pada kesempatan ini mengucapkan terima kasih kepada Direktorat Jenderal Penguatan Riset dan Pengembangan Kementerian Riset, Teknologi, dan Pendidikan Tinggi Republik Indonesia atas bantuan dana untuk Penelitian Dosen Pemula (PDP) pada tahun 2018.

\section{DAFTAR PUSTAKA}

[1]. Hafiludin. (2015). Analisis Kandungan Gizi Pada Ikan Bandengyang Berasal Dari Habitat Yang Berbeda. Jurnal Kelautan, Vol. 8 (1): 37-43.

[2]. Ball, D. V. and K. V. Rao. (1984). Marine Fisheries. Mc. Graw Hill Publishing Company Limited, New Delhi. India.472 halaman.

[3]. Kuncoro, Eko Budi. dan Wiharto, F. E. Ardi. (2009). Ensiklopedia Populer Ikan Air Laut. Lily Publisher. Yogyakarta. 122 halaman

[4]. A Suryana, B Wiryawan,D R Monintja, dan E S Wiyono. (2012). Analisis Keberlanjutan Rapfishdalam Pengelolaan Sumber Daya, Ikan Kakap Merah(Lutjanus sp.) Di Perairan Tanjungpandan. BULETIN PSP, Vol. 20 (1): 45-59

[5]. E Nurdin dan Hufiadi. (2006). Selektivitas Alat Tangkap Ikan Pari Di Perairan Laut Jawa. BAWAL, Vol. 1 (1): 25-30 
$\mathcal{H a l}: 26-30$

[6]. K Fatah dan Asyari. (2011). Beberapa Aspek Biologi Ikan Sembilang (Plotosus canius) Di Perairan Estuaria Banyuasin, Sumatera Selatan. BAWAL Vol.3 (4) :225-230

[7]. Walsh WA, Bigelow KA, Sender KL. (2009). Decreases in shark catches and mortality in the Hawa ii-based longline fishery as documented by fishery observers. Marine and Coastal Fisheries: Dynamics, Management and Ecosystem Science,1(1): 270-282 